\title{
Probiotic products in Canada with clinical evidence: What can gastroenterologists recommend?
}

\author{
Gregor Reid BSc (Hons) PhD MBA ARM CCM, Kingsley Anukam PhD, Tara Koyama BSc Hons
}

\begin{abstract}
G Reid, K Anukam, T Koyama. Probiotic products in Canada with clinical evidence: What can gastroenterologists recommend? Can J Gastroenterol 2008;22(2):169-175.

Probiotics, defined as 'live microorganisms, which when administered in adequate amounts, confer a health benefit on the host', are finally becoming an option for gastroenterologists in Canada, after being available for many years in Japan, Europe and the United States of America. Unfortunately, Health Canada and the US Food and Drug Administration have not controlled the use of the term 'probiotic' or put into place United Nations and World Health Organization guidelines. The net result is that a host of products called 'probiotics' are available but are not truly probiotic. The aim of the present review was to discuss the rationale for probiotics in gastroenterology, and specifically examine which products are options for physicians in Canada, and which ones patients might be using. It is hoped that by clarifying what probiotics are, and the strengths and limitations of their use, specialists will be better placed to make recommendations on the role of these products in patient care. In due course, more clinically documented probiotics will emerge, some with therapeutic effects based on a better understanding of disease processes.
\end{abstract}

Key Words: Canada; Gastroenterology; Prevention; Probiotics; Treatment

$\mathrm{M}$ edical school training in Canada has not tended to place much emphasis on the role of indigenous bacteria and health, even though we would be dead without our microbiota and they outnumber our cells 10:1. At best, graduates emerge having received lectures on a few pathogenic organisms. Specialization in gastroenterology requires a more comprehensive understanding of clinical outcomes derived from bacterial infections, but the importance of the indigenous gut microbes or probiotics is not emphasized. As a better understanding of inflammatory bowel disease (IBD), irritable bowel syndrome (IBS), pouchitis and colon cancer emerges, the role of microbes in causation and remediation of these conditions is becoming more intently investigated. Moreover, the use of probiotics (defined as "live microorganisms, which when administered in adequate amounts, confer a health benefit on the host" [1]) as an adjunct to patient management, is currently a hot topic. However, in practical terms, gastroenterologists need to be assured that any probiotics being taken by, or recommended for, their patients have undergone appropriate
Les produits probiotiques au Canada et les données cliniques : que peuvent recommander les gastroentérologues?

Les probiotiques, définis comme des « microorganismes vivants, qui produisent un effet bénéfique sur l'hôte lorsqu'ils sont administrés en quantité suffisante », offrent maintenant de véritables possibilités de traitement aux gastroentérologues au Canada après avoir été rendus accessibles bien des années auparavant au Japon, en Europe et aux ÉtatsUnis. Malheureusement, Santé Canada et la Food and Drug Administration n'ont pas défini l'emploi du terme «probiotique » ou mis en œuvre les lignes directrices de l'Organisation des Nations Unies ou de l'Organisation mondiale de la santé. Aussi une foule produits vendus sur le marché et affichant l'allégation " probiotiques » ne le sont-ils pas vraiment. La présente recherche documentaire visait à examiner l'utilisation raisonnée des probiotiques en gastroentérologie, et plus précisément à déterminer quels produits offraient aux médecins de véritables possibilités de traitement au Canada et lesquels pourraient être utilisés par les patients. Nous espérons que les éclaircissements sur la nature des probiotiques, de même que sur leurs avantages et leurs inconvénients, permettront aux spécialistes de formuler des recommandations plus précises sur le rôle de ces produits dans le traitement des maladies. Enfin, d'autres produits probiotiques documentés sur le plan clinique, dont certains seront dotés de propriétés thérapeutiques fondées sur une meilleure compréhension des processus pathologiques, arriveront un jour sur le marché. clinical investigation. The present review will address the rationale for probiotic use and the product options currently available in Canada.

\section{THE RATIONALE FOR PROBIOTICS IN THE GUT}

The rationale for replenishment of the gut flora (microbiota) is twofold. First, ancestral humans had a diet that was high in plant roots (a prebiotic food that promotes the growth of lactobacilli and bifidobacteria) and lactic acid bacteria (fermentation processes were commonly used to prepare and preserve food) (2). Thus, some would argue that the relatively rapid change to current diets (compared with the slow change in human genomics), where the focus is on two-year shelf-life and sterilized products, equates to a recipe for health problems. Second, because one-half of adult fecal weight is bacteria, how does this process affect the remaining microbes, and how does diet alter the microbial composition? Given the ability of bacteria to modulate the immune system and epithelial function,

Canadian Research $\mathcal{E}$ Development Centre for Probiotics, Lawson Health Research Institute, Departments of Microbiology $\mathcal{E}$ Immunology, and

Surgery, University of Western Ontario, London, Canada

Correspondence: Dr Gregor Reid, Canadian Research EO Development Centre for Probiotics, Lawson Health Research Institute, F2-116,

268 Grosvenor Street, London, Ontario N6A 4V2. Telephone 519-646-6100 ext 65256, fax 219-646-6031, e-mail gregor@uwo.ca,

Web site www.crdc-probiotics.ca

Received for publication March 8, 2007. Accepted August 22, 2007 
translocate the gut wall and produce substances that affect pain receptors (3-6), it seems reasonable to attempt to manipulate the composition of these organisms through the ingestion of beneficial ones.

One hundred years ago, Nobel Laureate Eli Metchnikoff reported an association between the ingestion of fermented milk and the long life of Bulgarian peasants (7). More recently, a study in drosophila also reported a correlation between a long life and beneficial microbes in the gut (8). It seems timely to examine the extent to which probiotics can help to restore and maintain human health.

\section{IBD}

Controversy continues to surround the cause of ulcerative colitis (UC), pouchitis and Crohn's disease. Only after the emergence of techniques that allow for the identification of culturable and nonculturable organisms is it now possible to determine the extent, if any, that the cause and continuation of these diseases relate to microbes. There is evidence in some patients that Crohn's disease may be a nonspecific chronic transmural inflammatory condition associated with a mutation in the NOD2 gene, while the presence of Mycobacterium paratuberculosis has been suggested as having a possible role in the continuation of disease (9). Other studies suggest an association between Escherichia coli and granulomas of Crohn's disease (10), but with commensal $E$ coli being adherent in the gut, further studies are needed to determine whether diseaseassociated strains express particular virulence properties. Serological testing has demonstrated reactivity to microbial antigens from E coli and Saccharomyces cerevisiae in Crohn's disease $(11,12)$, and the report of mucosal lymphocyte proliferation in response to an UC patient's own flora (13) are suggestive of a role of intestinal microbes in IBD. Using automated ribosomal intergenic spacer analysis and terminal restriction fragment length polymorphisms, a recent study in Winnipeg of biopsies from 10 Crohn's disease patients and 10 UC patients led to the hypothesis that potential pathogens colonize the gut tissue, inducing inflammation and causing a decline in microbial diversity (14).

The term 'colonizing' is often used loosely. It should mean that an organism is able to survive, grow and remain in a given site for extended periods of time. This is not always easy to confirm, and biopsy samples collected from the intestinal epithelium of a patient who has been cleansed before sampling may not be representative of the in situ situation. Likewise, tissue or mucin samples that are fixed may produce artifacts, while stool samples only show what is excreted and not necessarily what is colonizing a particular site. For probiotic applications, the organisms populate for a period of time, but never really colonize and remain. Thus, these products have to be taken on a regular basis so that the effects the organisms convey as they pass along the intestinal tract are continually delivered.

It is not known why major changes occur in the gut microbiota, apart from when infection arises, nor is it known whether the microbial changes occur as a result of physiological problems, or whether they actually cause these disorders. Nevertheless, a reduction in diversity of the microbiota and increased dominance by species such as hydrogen sulfideproducing bacteria has been associated with pouchitis (15) and ankylosing spondylitis (16), while a decreased presence of bifidobacteria has been associated with IBD (17). Thus, microbial changes have been shown to correlate with inflammatory conditions, although the different proportions of bacteria between healthy and diseased patients may only change subtly, making it more difficult to determine whether a single organism's alteration is the actual cause of the disease (18).

\section{IBS}

IBS is a chronic disorder that affects a relatively large percentage of the adult population. It is characterized by symptoms of abdominal pain, abdominal distension and a change in bowel habit, in the absence of structural abnormalities. The condition is multifactorial, but there appears to be an alteration in gut microbiota through the use of antibiotics, as well as following infectious diarrheal disease that contributes to disruption of the indigenous flora, alteration of barrier function and immune modulation (19-23).

The Canadian waterborne E coli outbreak has led to studies investigating the association between disruption of the microbiota and infection, and long-term IBS. In a study of 2069 eligible study participants, Rome I criteria were met by 71 of 701 controls (10.1\%) versus 249 of 904 subjects with self-reported gastroenteritis (27.5\%) and 168 of 464 subjects with clinically suspected gastroenteritis $(36.2 \%)$. The authors have concluded that postinfectious IBS is common after gastroenteritis (21).

It has been suggested that postinfectious IBS patients have a better prognosis than those with idiopathic IBS (24). Although the underlying mechanism of the condition is not clear, inflammation results in increased enterochromaffin cells, $\mathrm{T}$ lymphocytes, intestinal permeability, colonic transit time, and a variety of immunological abnormalities (24). Because lactobacilli and bidifobacteria have been shown to affect $\mathrm{T}$ cells, gut permeability, transit time and diarrhea, it makes good sense to consider whether the use of probiotics can alleviate gastrointestinal disorders.

\section{PROBIOTICS IN GASTROENTEROLOGY}

In addition to providing an updated definition of probiotics, the Expert Panel of the United Nations and the World Health Organization (WHO) also developed guidelines to describe what is meant by the term 'probiotic' $(25,26)$. This necessitates proper identification and classification of the organisms, suitable and shelf-stable formulation, appropriate randomized clinical efficacy evidence, and safety assessment. Unfortunately, many so-called probiotics do not meet these criteria, and indeed too many have been shown to contain wrongly labelled organisms, contaminants or significantly fewer viable cells than required (27-30). This makes it difficult to then assess reviews and meta-analyses of probiotics, because undocumented strains and products are often not excluded from these assessments. Nevertheless, the Food and Agriculture Organization (FAO) and WHO, as well as numerous reviews have stated that there is sufficient evidence to show that probiotic strains can help prevent and treat diarrheal episodes, and enhance intestinal health $(1,31,32)$. The most documented strains for these effects are Lactobacillus rhamnosus GG, Lactobacillus reuteri SD2112, and Saccharomyces cerevisiae subspecies boulardii lyo (32-34).

The question of how the efficacy of probiotics is evaluated, overall, is somewhat contentious and certainly not an easy one to answer. In addition to only including properly produced and clinically documented products, issues of study design, patient pool, sex, duration, dosage and delivery form all come into 
play. In addition, when assessing the use of probiotics or any other remedy to prevent diarrhea, it is easy to standardize the antibiotics used, but not the exposure rates to different gastrointestinal pathogens. This is especially true for traveller's diarrhea. Failure to show probiotics being effective for this problem could be explained by differences in exposure to pathogens, as well as by the authors of the meta-analysis, including completely unproven products such as BD Lactinex (Becton, Dickinson and Company, USA) (35).

In a meta-analysis of six randomized, placebo-controlled trials of 766 children, treatment with probiotics compared with placebo reduced the risk of antibiotic-associated diarrhea (AAD) from $28.5 \%$ to $11.9 \%$ (RR $0.44,95 \%$ CI 0.25 to 0.77 , random effects model) (36). A preplanned subgroup analysis showed that a reduction in the risk for AAD was associated with the use of $L$ rhamnosus GG (two randomized, controlled trials [RCTs] with 307 participants; RR 0.3, 95\% CI 0.15 to 0.6), S cerevisiae subspecies boulardii lyo (one RCT with 246 participants; RR 0.2, 95\% CI 0.07 to 0.6) or Bifidobacterium lactis plus Streptococcus thermophilus (one RCT with 157 participants; RR 0.5, 95\% CI 0.3 to 0.95). Of these, only $S$ cerevisiae subspecies boulardii lyo is available in Canada (as Florastor, Medical Futures Inc, Canada).

A Turkish study of 151 patients showed a significant reduction in $\mathrm{AAD}(1.4 \%$ versus $9 \% ; \mathrm{P}<0.05)$ with $\mathrm{S}$ cerevisiae subspecies boulardii lyo daily treatment given along with antibiotics (37). In a Polish study, 269 children (aged six months to 14 years) with otitis media and/or respiratory tract infections were enrolled in a double-blind, randomized, placebo-controlled trial to receive standard antibiotic treatment plus $250 \mathrm{mg}$ of $\mathrm{S}$ cerevisiae subspecies boulardii lyo orally twice daily for the duration of antibiotic therapy (38). The prevalence of acute watery diarrhea (three or more loose or watery stools per day for $48 \mathrm{~h}$ or longer, occurring during or up to two weeks after the antibiotic therapy) was significantly lower in the probiotic group (8\% versus 23\%; RR 0.3, 95\% CI 0.2 to 0.7 ). The $S$ cerevisiae subspecies boulardii lyo also reduced the risk of AAD caused by $\mathrm{C}$ difficile (3.4\% versus $17.3 \%$ ).

A study of 50 children in Pakistan with the same average frequency of stools in $S$ cerevisiae subspecies boulardii lyo and control groups at the time of inclusion in a randomized study, showed an effect of probiotics by day 3 . There was a reduction from 4.2 to 2.7 stools per day, and by day 6 , the number of stools per day went down to 1.6, compared with 3.3 stools per day with the placebo (39). The duration of diarrhea was 3.6 days in the $S$ cerevisiae subspecies boulardii lyo group versus 4.8 days in the control group $(\mathrm{P}=0.001)$. Over the following two months, the probiotic-treated children had a significantly lower frequency of episodes $(0.54)$ than the control group (1.08).

There are preliminary data from a 25-patient study suggesting that $S$ boulardii given three times daily, along with mesalazine to patients suffering from mild-to-moderate clinical flare-up of UC, can help with clinical remission (17 of 25 patients attained remission) (40). Further studies are warranted with this probiotic for UC and other more complicated gastrointestinal patients. During such use of the product, staff need to be trained in handling these live organisms, because some cases of fungemia have resulted through contamination of intravenous lines, as well as possible gut translocation (41). Particular care is needed for immune-suppressed and critically ill patients to reduce the risk of fungemia.
In an effort to globally examine the usefulness of probiotics to prevent diarrhea, McFarland (42) pooled heterogenous studies. This meta-analysis concluded that probiotics could be effective in some cases, including the prevention of relapse following successful antibiotic treatment of $\mathrm{C}$ difficile diarrhea. Dendukuri and Brophy (43) and Lewis (44) criticized the analysis for the pitfalls of comparing studies with different strains, outcomes, doses and duration of treatment, and for including adults and children. The latter inflated the potential side effects of probiotics, as did Segarra-Newnham (45) based on a serious lack of evaluation of the literature and understanding of probiotics, and failure to cite various safety reports $(46,47)$. Furthermore, safe use of $L$ rhamnosus GG and GR-1 in HIV and IBD patients (48-50) counters Lewis's unsubstantiated opinion that probiotic strains are potentially hazardous. Lewis (44) concluded that he was not convinced that probiotics could reduce the recurrence of $\mathrm{C}$ difficile; however, in a rebuttal, McFarland (51) re-explained and reaffirmed her initial findings.

Readers of these papers need to make their own conclusions as to the merits of $L$ rhamnosus GG and $S$ cerevisiae subspecies boulardii lyo in preventing diarrhea. For our part, we side with the viewpoint of McFarland, but believe that further studies are needed on patients who are already infected with $\mathrm{C}$ difficile, because such cases have still not been proven conclusively to be more effectively cured by the addition of probiotics.

In terms of management of patients seen by gastroenterologists in Canada, a longer discussion will follow. But, for subjects who are without any underlying gastrointestinal disorders and travelling to the developing world or receiving antibiotics, it seems reasonable to use either $L$ rhamnosus GG or $S$ cerevisiae subspecies boulardii lyo to attempt to prevent or reduce the severity of diarrhea, albeit only the latter product is available in Canada (as Florastor).

The case in favour of probiotics to augment the cure of bacterial and viral diarrheal disease is quite convincing, especially in children who are coadministered with oral rehydration. In general, the duration of the condition is shortened by one to two days, or in some cases, more (52-56).

With respect to IBS, a recent review suggested that there is a rationale for using probiotics to correct a dysfunctional relationship between the indigenous flora and the host (57). While studies with Bifidobacterium infantis 35624 show relief of some symptoms of IBS $(58,59)$, VSL\#3 (VSL Pharmaceuticals Inc, Canada) (discussed in more detail below) reduces flatulence scores and retards colonic transit $(60,61)$, further studies with these and other strains are needed to determine dosage, duration and extent of clinical benefits across the spectrum of IBS complaints.

Although Helicobacter pylori is not a pathogen commonly found in the stomach of Canadians, it is a major cause of ulcers and cancer in other parts of the world, especially in Asia. A number of studies have been performed to assess the use of probiotics against $H$ pylori. For the most part, there is little conclusive evidence to indicate that probiotics can eradicate $H$ pylori on their own. However, there are some data to indicate that certain probiotics can either augment reduction in symptoms, or reduce the side effects of antibiotic therapy. Two examples are given. In a randomized, double-blind, placebo-controlled study, 79 subjects received 12 weeks of placebo or Bifidobacterium bifidum YIT 4007 fermented milk. There was improvement in upper gastrointestinal symptoms 
TABLE 1

Probiotics and so-called 'probiotics' that patients might be using in Canada

\begin{tabular}{|c|c|c|}
\hline Product & Microbial content & Clinical data and claims* \\
\hline $\begin{array}{l}\text { Florastor, Medical Futures Inc, } \\
\text { Canada }\end{array}$ & $\begin{array}{l}\text { Saccharomyces boulardii lyo; } \\
\text { proven probiotic }\end{array}$ & Clinically shown to treat and help prevent diarrhea in adults and children \\
\hline $\begin{array}{l}\text { Activia yogurt, Danone, } \\
\text { Canada }\end{array}$ & $\begin{array}{l}\text { Bifidobacterium animalis DN 117-001, } \\
\text { proven probiotic }\end{array}$ & Clinically shown to improve transit time (regularity) \\
\hline $\begin{array}{l}\text { VSL\#3, VSL Pharmaceuticals } \\
\text { Inc, Canada }\end{array}$ & $\begin{array}{l}\text { Eight strains of lactobacilli, bifidobacteria } \\
\text { and streptococcus; proven probiotic }\end{array}$ & $\begin{array}{l}\text { Clinically shown to help prevent pouchitis and retain remission, and is } \\
\text { an adjunct treatment for mild-to-moderate ulcerative colitis }\end{array}$ \\
\hline $\begin{array}{l}\text { Fem-Dophilus, Jarrow } \\
\text { Formulas, USA }\end{array}$ & $\begin{array}{l}\text { Lactobacillus rhamnosus GR-1 and } \\
\text { Lactobacillus reuteri RC-14; proven } \\
\text { probiotic }\end{array}$ & Anti-inflammatory and anti-infective effects \\
\hline $\begin{array}{l}\text { Bio-K+ CL1285, Bio-K+ Pharma, } \\
\text { Canada }\end{array}$ & Several strains & $\begin{array}{l}\text { Still waiting for peer-reviewed data on company claims that it helps prevent } \\
\text { diarrhea and Clostridium difficile }\end{array}$ \\
\hline $\begin{array}{l}\text { Natrel pro, Agropur, } \\
\text { Division Natrel, Canada }\end{array}$ & $\begin{array}{l}\text { Bifidobacterium lactis BB-12 and } \\
\text { unknown Lactobacillus }\end{array}$ & $\begin{array}{l}\text { No data with this formulation, but the BB-12 strain is used in several formulations } \\
\text { for improved gut health }\end{array}$ \\
\hline $\begin{array}{l}\text { Yoptimal immuni+, Yoplait, } \\
\text { Canada }\end{array}$ & $\begin{array}{l}\text { Lactobacillus acidophilus LA-5 } \\
\text { and } B \text { lactis BB-12 }\end{array}$ & $\begin{array}{l}\text { No data with this milk formulation, but BB- } 12 \text { and LA- } 5 \text { have been used } \\
\text { extensively in several formulations for improved gut health }\end{array}$ \\
\hline $\begin{array}{l}\text { Lactibiane, PiLeJe Micronutrition, } \\
\text { Canada }\end{array}$ & Unknown four-strain combination & No known peer-reviewed publications \\
\hline $\begin{array}{l}\text { Lacidofil, Institut Rosell, } \\
\text { Canada }\end{array}$ & Lactobacillus Rosell-52 and Rosell-11 & One clinical trial with antibiotics, in which this product appears to prevent diarrhea \\
\hline $\begin{array}{l}\text { Bacid, Aventis Group, } \\
\text { Canada }\end{array}$ & $L$ rhamnosus (formerly $L$ acidophilus) & Grandfathered in Canada for gut health, but no known peer-reviewed data \\
\hline $\begin{array}{l}\text { Probiotic Frozen Yogurt, } \\
\text { Yogen Fruz, Canada }\end{array}$ & Unknown bacterial content & $\begin{array}{l}\text { Associates itself with probiotics, which the company claims reduce colon cancer, } \\
\text { lower cholesterol and prevent infections; There are no published data on this } \\
\text { frozen yogurt }\end{array}$ \\
\hline $\begin{array}{l}\text { Oasis Health Break with } \\
\text { Probiotics, A. Lassonde } \\
\text { Inc, Canada }\end{array}$ & Bifidobacterium bifidus and $L$ acidophilus & No claims and no publications on this juice \\
\hline $\begin{array}{l}\text { YogActive cereal, Belgo \& Bellas, } \\
\text { Canada }\end{array}$ & $L$ acidophilus beads with cereal & No known peer-reviewed, published clinical data \\
\hline $\begin{array}{l}\text { Jamieson Lactobacillus } \\
\text { acidophilus, Jamieson } \\
\text { Laboratories, Canada }\end{array}$ & $\begin{array}{l}L \text { acidophilus and } L \text { rhamnosus } \\
\text { in capsules }\end{array}$ & $\begin{array}{l}\text { Claims to aid digestion, treat antibiotic-induced intestinal side effects, } \\
\text { help prevent traveler's diarrhea and support anticandida destruction; } \\
\text { strain types are not designated; and } \\
\text { no known peer-reviewed clinical data on its claims }\end{array}$ \\
\hline $\begin{array}{l}\text { Align, Proter \& Gamble, USA } \\
\text { (purchase on-line at } \\
\text { www.aligngi.com/index.shtml) }\end{array}$ & $\begin{array}{l}\text { Bifidobacterium infantis } 35624 \text {; proven } \\
\text { probiotic }\end{array}$ & For relief from inflammatory bowel syndrome \\
\hline $\begin{array}{l}\text { TuZen, Ferring } \\
\text { Pharmaceuticals, Canada }\end{array}$ & Lactobacillus plantarum 299v & $\begin{array}{l}\text { Claimed for use in inflammatory bowel syndrome, but one study failed to show } \\
\text { an effect (74) } \\
\text { Clinical evidence exists for the strain to reduce infection in surgery patients }\end{array}$ \\
\hline
\end{tabular}

*Health Canada does not allow these claims unless the product is filed as a drug

(62). In a study of $40 \mathrm{H}$ pylori-positive children (median age 12.3 years) who were consecutively treated with 10-day sequential therapy (omeprazole plus amoxicillin for five days, and omeprazole plus clarithromycin plus tinidazole for another five days), and blindly randomly assigned to receive either $L$ reuteri ATCC $55730\left(1 \times 10^{8}\right.$ colony-forming units $)$ or placebo, there was a significant reduction in the Gastrointestinal Symptoms Rating Scale score during eradication therapy $(4.1 \pm 2$ versus $6.2 \pm 3 ; \mathrm{P}<0.01)$ and at the end of follow-up $(3.2 \pm 2$ versus $5.8 \pm 3.4 ; \mathrm{P}<0.009)(63)$.

\section{WHAT IS AVAILABLE IN CANADA?}

Lactobacilli and bifidobacteria are the most commonly used genera for probiotics due to their long track record of safety. In Canada, a number of so-called probiotic products are sold, but very few meet the FAO/WHO guidelines (25) for being probiotic, and do not appear to have been appropriately clinically tested in the form in which they are sold (Table 1). Without such verification of a specific benefit to humans, products are not truly probiotic. That does not mean they are ineffective or of poor quality; simply, they should be called something other than probiotic so as not to confuse physicians or consumers. This is important for the reasons noted above, where all products called probiotic are then assessed together, avoiding skewing of the meta-analysis. The distinction is an important one for physicians and consumers to understand. If something is called a probiotic, there has to be a standard to which this product is measured (64). These include proper strain identification and speciation (not all $L$ rhamnosus products are probiotic); production under good manufacturing practices with end of shelf-life viable counts at the minimum required for health effects; testing of the final product for safety 
and efficacy in humans; and preferably, some understanding of the mechanisms of action and scope of benefits (26). Unfortunately, Health Canada and the US Food and Drug Administration have not yet embraced or enforced these guidelines; therefore, companies have been calling their products probiotic, with very few meeting the appropriate standards. Thus, it is impossible to know what strains are in some products, and which studies have been performed and published in suitable peer-reviewed journals, making it impossible to assess their benefits and usefulness. So, how can a physician recommend them?

A search on <www.google.ca> or visit to the local health food store, apothecary or pharmacist selling 'probiotics' does not necessarily lead to clarity, because many companies are making claims that, quite frankly, are not, and will not be, approved by regulatory agencies. Of the probiotics available in Canada for gastrointestinal benefits, VSL\#3, Florastor, Activia (Danone, Canada) and possibly Lacidofil (Institut Rosell, Canada) are worthy of discussion.

VSL\#3 contains Lactobacillus casei, Lactobacillus plantarum, Lactobacillus acidophilus, Lactobacillus delbrueckii subspecies bulgaricus, Bifidobacterium longum, Bifidobacterium breve, Bifidobacterium infantis and Streptococcus salivarius subspecies thermophilus (65). In a recent study performed in Edmonton, Bibiloni et al (66) demonstrated the induction of remission in patients with active UC. Thirty-four ambulatory patients with active UC received open-label VSL\#3 $\left(3.6 \times 10^{12}\right)$ bacteria daily in two divided doses for six weeks. Intention-to-treat analysis demonstrated remission (UC Disease Activity Index score of 2 or less) in 53\% $(n=18)$; response (decrease in UC Disease Activity Index score of 3 or more, but final score of 3 or more) in $24 \%(n=8)$; no response in $9 \%(n=3)$; worsening in $9 \%(n=3)$; and failure to complete the final sigmoidoscopy assessment in $5 \%(n=2)$. No biochemical or clinical adverse events related to VSL\#3 were reported. Two of the species contained within the VSL\#3 product were detected by polymerase chain reaction (PCR) and denaturing gradient gel electrophoresis in biopsies collected from three patients in remission; however, this does not $100 \%$ confirm that the strains were from the product, and it raises the question of what happened to the other six strains.

In another study on maintenance of remission in pouchitis patients, Kuhbacher et al (67) showed high efficacy. The mucosa-associated pouch microbiota were investigated before and after therapy with VSL\#3 by analysis of endoscopic biopsies using ribosomal DNA/RNA-based community fingerprint analysis, clone libraries, real-time PCR and fluorescence in situ hybridization. Bacterial diversity was increased and fungal diversity was reduced in patients in remission maintained with VSL\#3 ( $\mathrm{P}=0.001)$. Real-time PCR experiments demonstrated that VSL\#3 increased the total number of bacterial cells $(\mathrm{P}=0.002)$ and modified the spectrum of bacteria toward anaerobic species. Using taxa-specific clone libraries for lactobacilli and bifidobacteria, it was found that the richness and spectrum of these bacteria were altered under probiotic therapy.

As briefly cited above, a study at the Mayo Clinic (Rochester, Minnesota, USA) enrolled 48 patients with Rome II IBS, and randomly assigned them in a parallel group, double-blind design to placebo or VSL\#3 twice daily (31 patients received four weeks and 17 patients received eight weeks of treatment) (61). Pre- and post-treatment colonic transit measurements were performed using scintigraphy with indium-111-labelled charcoal. Treatment with VSL\#3 was associated with reduced flatulence over the entire treatment period (placebo, 39.5 \pm 2.6 versus VSL $\# 3,29.7 \pm 2.6$; $\mathrm{P}=0.011$ ); similarly, during the first four weeks of treatment, flatulence scores were reduced (placebo, 40.1 \pm 2.5 versus VSL\#3, $30.8 \pm 2.5 ; \mathrm{P}=0.014$ )

Danone's Activia yogurt, containing Bifidobacterium animalis (lactis) DN-173 010, has been tested for regularity of bowel movement and its ability to survive in the gastrointestinal tract $(68,69)$. In a double-blind, cross-over study by Marteau et al (70), 36 healthy women were enrolled in four consecutive 10 -day periods. During periods 2 and 4 , they ingested three $125 \mathrm{~g}$ cups per day of a fermented milk containing B animalis (lactis) DN-173 010 or a control without bifidobacteria. Periods 1 and 3 were run-in and washout periods, respectively. The total and segmental colonic transit times were assessed using a pellet method. In 12 subjects, all stools were collected and analyzed for $\mathrm{pH}$, fecal weight, bacterial mass and bile acids. The study found that the total and sigmoid transit times were significantly shorter during dosing with $B$ animalis than during the control period. The report concluded that B animalis DN-173 010 shortens the colonic transit time in healthy women. This product also appears to aid in motility when only one cup is consumed per day, but studies are needed with this protocol in Canada to measure its usefulness in gastroenterology patients.

A report published only in a company handout showed that two Canadian-produced strains whose species were not given, Lactobacillus Rosell-52 and Rosell-11 in a product called Lacidofil, could potentially reduce diarrhea and clostridial toxin in the stool of children (71). The former was noted in $7.4 \%$ of 27 subjects given antibiotics and probiotics, compared with $36.7 \%$ of 30 subjects. Clostridium toxin in feces was also different (7.4\% versus $43.3 \%$ ). Further studies are required and the work performed by Ivanko (71) needs to be published in full in a peer-reviewed journal.

A probiotic yogurt containing $L$ rhamnosus GR-1 and $L$ reuteri $\mathrm{RC}-14$ has been shown to have anti-inflammatory benefits in 20 patients with IBD, 15 of whom had Crohn's disease and five had UC (50). These organisms have documented anti-inflammatory activity $(72,73)$. After one month's consumption of the probiotic yogurt, the proportion of $\mathrm{CD} 4^{+} \mathrm{CD} 25^{\text {high }} \mathrm{T}$ cells increased significantly $(\mathrm{P}=0.007)$ in IBD patients (mean $0.84 \%$ before and $1.25 \%$ after treatment), correlating with the decrease in the percentage of TNF-alpha (TNF- $\alpha$ ) or interleukin (IL)-12-producing monocytes and dendritic cells. The basal proportion of TNF- $\alpha$-positive (+)/IL-12+ monocytes and myeloid dendritic cells decreased in both groups, but stimulated cells only decreased in IBD patients. In addition, serum IL-12 and proportions of IL-2+ and CD69+ $\mathrm{T}$ cells from stimulated cells decreased in IBD patients receiving probiotics.

\section{CONCLUSIONS}

The rapid emergence of interest in probiotics has coincided with an increase in products on the market, some claiming to be probiotic without appropriate clinical documentation. There has also been an increase in people trying probiotics for various health effects or treatment of intestinal disorders. Scientific studies have increased significantly in the past five years, providing a better understanding of the strengths and limitations of probiotic strains. Three things are now needed 
in Canada to move this field along to a position where gastroenterologists can more frequently recommend the use of probiotics for specific benefits (1). First, Health Canada, whether through its biological, pharmaceutical, food or natural health product divisions, needs to demand that products meet FAO/WHO guidelines or equally stringent standards in terms of strain characterization, product formulation and clinical evidence of beneficial effects, or to make the products be referred to as something other than probiotic. This will make it easier for consumers and physicians to track studies with these products, and evaluate their usefulness (2). Second, more grant funding is needed to support a fundamental understanding of the intestinal microbiota and probiotic organisms, and their mechanisms of action (3). Third, lectures on beneficial microbes need to be integrated into the biomedical curricula and educational information made more widely available to lay people and the media, to differentiate true probiotics from products that are undocumented. For now, several products can be of value for intestinal health, and their use could provide an important means to reduce the burden placed on gastroenterologists, or to be used by these specialists as anadjunctive therapy for managing intestinal disorders.

ACKNOWLEDGEMENTS: The work on probiotics performed in our lab is supported by grants from the Ontario Ministry of Agriculture, Food and Rural Affairs; the Natural Sciences and Engineering Research Council of Canada; the Advanced Foods \& Materials Network; and the Canadian Institutes of Health Research.

CONFLICT OF INTEREST: The authors unequivocally express no conflict of interest in this contribution. Dr Reid holds patents for L rhamnosus GR-1 and L reuteri RC-14 that are not pertinent to gastrointestinal therapy.

\section{REFERENCES}

1. FAO/WHO. Health and nutritional properties of probiotics in food including powder milk with live lactic acid bacteria.

$<$ http://www.who.int/foodsafety/publications/fs_management/en/pro biotics.pdf> (Version current at January 21, 2008).

2. Leach JD. Evolutionary perspective on dietary intake of fibre and colorectal cancer. Eur J Clin Nutr 2007;61(1):140-2.

3. Martins FS, Rodrigues AC, Tiago FC, et al. Saccharomyces cerevisiae strain 905 reduces the translocation of Salmonella enterica serotype typhimurium and stimulates the immune system in gnotobiotic and conventional mice. J Med Microbiol 2007;56:352-9.

4. Rousseaux C, Thuru X, Gelot A, et al. Lactobacillus acidophilus modulates intestinal pain and induces opioid and cannabinoid receptors. Nat Med 2007;13:35-7.

5. Saavedra JM. Use of probiotics in pediatrics: Rationale, mechanisms of action, and practical aspects. Nutr Clin Pract 2007;22:351-65.

6. Zocco MA, Ainora ME, Gasbarrini G, Gasbarrini A. Bacteroides thetaiotaomicron in the gut: Molecular aspects of their interaction. Dig Liver Dis 2007;39:707-12.

7. Metchnikoff E. The Prolongation of Life. Optimistic Studies. New York: Putman's Sons, 1908;161-83.

8. Brummel T, Ching A, Seroude L, Simon AF, Benzer S. Drosophila lifespan enhancement by exogenous bacteria. Proc Natl Acad Sci U S A 2004;101:12974-9.

9. Sechi LA, Mura M, Tanda E, Lissia A, Fadda G, Zanetti S. Mycobacterium avium sub. paratuberculosis in tissue samples of Crohn's disease patients. New Microbiol 2004;27:75-7.

10. Ryan P, Kelly RG, Lee G, et al. Bacterial DNA within granulomas of patients with Crohn's disease - detection by laser capture microdissection and PCR. Am J Gastroenterol 2004;99:1539-43.

11. Landers CJ, Cohavy O, Misra R, et al. Selected loss of tolerance evidenced by Crohn's disease-associated immune responses to autoand microbial antigens. Gastroenterology 2002;123:689-99.

12. Arnott ID, Landers CJ, Nimmo EJ, et al. Sero-reactivity to microbial components in Crohn's disease is associated with disease severity and progression, but not NOD2/CARD15 genotype. Am J Gastroenterol 2004;99:2376-84.

13. Duchmann R, May E, Heike M, et al. T cell specificity and cross reactivity towards enterobacteria, bacteroides, bifidobacterium, and antigens from resident intestinal flora in humans. Gut 1999;44:812-8.

14. Sepehri S, Kotlowski R, Bernstein CN, Krause DO. Microbial diversity of inflamed and noninflamed gut biopsy tissues in inflammatory bowel disease. Inflamm Bowel Dis 2007;13:675-83.

15. Ohge H, Furne JK, Springfield J, Rothenberger DA, Madoff RD, Levitt MD. Association between fecal hydrogen sulfide production and pouchitis. Dis Colon Rectum 2005;48:469-75.

16. Stebbings S, Munro K, Simon MA, et al. Comparison of the faecal microflora of patients with ankylosing spondylitis and controls using molecular methods of analysis. Rheumatology (Oxford) 2002;41:1395-401.

17. Subramanian S, Campbell BJ, Rhodes JM. Bacteria in the pathogenesis of inflammatory bowel disease. Curr Opin Infect Dis 2006;19:475-84.

18. Gophna U, Sommerfeld K, Gophna S, Doolittle WF, Veldhuyzen van Zanten SJ. Differences between tissue-associated intestinal microfloras of patients with Crohn's disease and ulcerative colitis. J Clin Microbiol 2006;44:4136-41.

19. Mendall MA, Kumar D. Antibiotic use, childhood affluence and irritable bowel syndrome (IBS). Eur J Gastroenterol Hepatol 1998;10:59-62.

20. Wang LH, Fang XC, Pan GZ. Bacillary dysentery as a causative factor of irritable bowel syndrome and its pathogenesis. Gut 2004;53:1096-101.

21. Marshall JK, Thabane M, Garg AX, Clark WF, Salvadori M, Collins SM, for the Walkerton Health Study Investigators. Incidence and epidemiology of irritable bowel syndrome after a large waterborne outbreak of bacterial dysentery. Gastroenterology 2006;131:445-50.

22. Quigley EM. Germs, gas and the gut; the evolving role of the enteric flora in IBS. Am J Gastroenterol 2006;101:334-5.

23. Riordan SM, Kim R. Bacterial overgrowth as a cause of irritable bowel syndrome. Curr Opin Gastroenterol 2006;22:669-73.

24. Rhodes DY, Wallace M. Post-infectious irritable bowel syndrome. Curr Gastroenterol Rep 2006;8:327-32.

25. FAO/WHO. Guidelines for the evaluation of probiotics in food. Report of a joints FAO/WHO Working Group on drafting guidelines for the evaluation of probiotics in food. $<\mathrm{ftp}: / / \mathrm{ftp}$.fao.org/es/esn/food/wgreport2.pdf> (Version current at December 18, 2007).

26. Reid G. The importance of guidelines in the development and application of probiotics. Curr Pharm Des 2005;11:11-6.

27. Hughes VL, Hillier SL. Microbiologic characteristics of Lactobacillus products used for colonization of the vagina. Obstet Gynecol 1990;75:244-8.

28. Zhong W, Millsap K, Bialkowska-Hobrzanska H, Reid G. Differentiation of Lactobacillus species by molecular typing. Appl Environ Microbiol 1998;64:2418-23.

29. Hamilton-Miller JM, Shah S, Winkler JT. Public health issues arising from microbiological and labelling quality of foods and supplements containing probiotic microorganisms. Public Health Nutr 1999;2:223-9.

30. Temmerman R, Scheirlinck I, Huys G, Swings J. Culture-independent analysis of probiotic products by denaturing gradient gel electrophoresis. Appl Environ Microbiol 2003;69:220-6.

31. Ljungh A, Wadstrom T. Lactic acid bacteria as probiotics. Curr Issues Intest Microbiol 2006;7:73-89.

32. Reid G. Safe and efficacious probiotics: What are they? Trends Microbiol 2006;14:348-52.

33. Huebner ES, Surawicz CM. Probiotics in the prevention and treatment of gastrointestinal infections. Gastroenterol Clin North Am 2006;35:355-65. 
34. Reid G, Sanders ME, Gaskins HR, et al. New scientific paradigms for probiotics and prebiotics. J Clin Gastroenterol 2003;37:105-18.

35. Takahashi O, Noguchi Y, Omata F, Tokuda Y, Fukui T. Probiotics in the prevention of traveler's diarrhea: Meta-analysis. J Clin Gastroenterol 2007;41:336-7.

36. Szajewska H, Ruszczynski M, Radzikowski A. Probiotics in the prevention of antibiotic-associated diarrhea in children: A metaanalysis of randomized controlled trials. J Pediatr 2006; $149: 367-72$

37. Can M, Besirbellioglu BA, Avci IY, Beker CM, Pahsa A. Prophylactic Saccharomyces boulardii in the prevention of antibiotic-associated diarrhea: A prospective study. Med Sci Monit 2006;12:PI19-22.

38. Kotowska M, Albrecht P, Szajewska H. Saccharomyces boulardii in the prevention of antibiotic-associated diarrhoea in children: A randomized double-blind placebo-controlled trial. Aliment Pharmacol Ther 2005;21:583-90.

39. Billoo AG, Memon MA, Khaskheli SA, et al. Role of a probiotic (Saccharomyces boulardii) in management and prevention of diarrhoea. World J Gastroenterol 2006;12:4557-60.

40. Guslandi M, Giollo P, Testoni PA. A pilot trial of Saccharomyces boulardii in ulcerative colitis. Eur J Gastroenterol Hepatol 2003;15:697-8.

41. Munoz P, Bouza E, Cuenca-Estrella M, et al. Saccharomyces cerevisiae fungemia: An emerging infectious disease. Clin Infect Dis 2005;40:1625-34.

42. McFarland LV. Diarrhoea associated with antibiotic use. BMJ 2007;335:54-5.

43. Dendukuri N, Brophy J. Inappropriate use of meta-analysis to estimate efficacy of probiotics. Am J Gastroenterol 2007;102;201.

44. Lewis S. Response to the article: McFarland LV. Meta-analysis of probiotics for the prevention of antibiotic-associated diarrhea and the treatment of Clostridium difficile disease. Am J Gasroenterol 2006.101:812-22. Am J Gastroenterol 2007;102:201-2.

45. Segarra-Newnham M. Probiotics for Clostridium difficile-associated diarrhea: Focus on Lactobacillus rhamnosus GG and Saccharomyces boulardii. Ann Pharmacother 2007;41:1212-21.

46. Reid G. Safety of Lactobacillus strains as probiotic agents. Clin Infect Dis 2002;35:349-50.

47. Salminen MK, Tynkkynen S, Rautelin H, et al. Lactobacillus bacteremia during a rapid increase in probiotic use of Lactobacillus rhamnosus GG in Finland. Clin Infect Dis 2002;35:1155-60.

48. Salminen MK, Tynkkynen S, Rautelin $\mathrm{H}$, et al. The efficacy and safety of probiotic Lactobacillus rhamnosus GG on prolonged, noninfectious diarrhea in HIV patients on antiretroviral therapy: A randomized, placebo-controlled, crossover study. HIV Clin Trials 2004;5:183-91.

49. Anukam KC, Osazuwa EO, Osadolor BE, Bruce AW, Reid G. Yogurt containing probiotic Lactobacillus rhamnosus GR-1 and L reuteri RC-14 helps resolve moderate diarrhea and increases CD4 count in HIV/AIDS patients. J Clin Gastroenterol 2007. (In press)

50. Lorea Baroja M, Kirjavainen PV, Hekmat S, Reid G. Anti-inflammatory effects of probiotic yogurt in inflammatory bowel disease patients. Clin Exp Immunol 2007;149:470-9.

51. McFarland LV. Response to Drs Ramnarace and Dendukuri. Am J Gastroenterol 2007;102:202-4.

52. Siitonen S, Vapaatalo H, Salminen S, et al. Effect of Lactobacillus GG yoghurt in prevention of antibiotic associated diarrhoea. Ann Med 1990;22:57-9.

53. Vanderhoof JA, Whitney DB, Antonson DL, Hanner TL, Lupo JV, Young RJ. Lactobacillus GG in the prevention of antibiotic-associated diarrhea in children. J Pediatr 1999;135:564-8.

54. Van Niel CW, Feudtner C, Garrison MM, Christakis DA. Lactobacillus therapy for acute infectious diarrhea in children: A meta-analysis. Pediatrics 2002;109(4):678-84.
55. Rosenfeldt V, Michaelsen KF, Jakobsen M, et al. Effect of probiotic Lactobacillus strains on acute diarrhea in a cohort of nonhospitalized children attending day-care centers. Pediatr Infect Dis J 2002;21:417-9.

56. Teitelbaum JE. Probiotics and the treatment of infectious diarrhea. Pediatr Infect Dis J 2005;24:267-8.

57. Quigley EM, Flourie B. Probiotics and irritable bowel syndrome: A rationale for their use and an assessment of the evidence to date. Neurogastroenterol Motil 2007;19:166-72.

58. O'Mahony L, McCarthy J, Kelly P, et al. Lactobacillus and Bifidobacterium in irritable bowel syndrome: Symptom responses and relationship to cytokine profiles. Gastroenterology 2005;128:541-51.

59. Whorwell PJ, Altringer L, Morel J, et al. Efficacy of an encapsulated probiotic Bifidobacterium infantis 35624 in women with irritable bowel syndrome. Am J Gastroenterol 2006;101:1581-90.

60. Kim HJ, Camilleri M, McKinzie S, et al. A randomized controlled trial of a probiotic, VSL $\# 3$, on gut transit and symptoms in diarrhoeapredominant irritable bowel syndrome. Aliment Pharmacol Ther 2003;17:895-904.

61. Kim HJ, Vazquez Roque MI, Camilleri M, et al. A randomized controlled trial of a probiotic combination VSL\# 3 and placebo in irritable bowel syndrome with bloating. Neurogastroenterol Motil 2005;17:687-96.

62. Miki K, Urita Y, Ishikawa F, et al. Effect of Bifidobacterium bifidum fermented milk on Helicobacter pylori and serum pepsinogen levels in humans. J Dairy Sci 2007;90:2630-40

63. Lionetti E, Miniello VL, Castellaneta SP, et al. Lactobacillus reuteri therapy to reduce side-effects during anti-Helicobacter pylori treatment in children: A randomized placebo controlled trial. Aliment Pharmacol Ther 2006;24:1461-8.

64. Gionchetti P, Rizzello F, Campieri M. Probiotics in gastroenterology. Curr Opin Gastroenterol 2002;18:235-9.

65. Chapman TM, Plosker GL, Figgitt DP. VSL\#3 probiotic mixture: A review of its use in chronic inflammatory bowel diseases. Drugs 2006;66:1371-87

66. Bibiloni R, Fedorak RN, Tannock GW, et al. VSL\#3 probioticmixture induces remission in patients with active ulcerative colitis. Am J Gastroenterol 2005;100:1539-46.

67. Kuhbacher T, Ott SJ, Helwig U, et al. Bacterial and fungal microbiota in relation to probiotic therapy (VSL\#3) in pouchitis. Gut 2006;55:833-41.

68. Pochart P, Marteau P, Bouhnik Y, Goderel I, Bourlioux P, Rambaud JC. Survival of bifidobacteria ingested via fermented milk during their passage through the human small intestine: An in vivo study using intestinal perfusion. Am J Clin Nutr 1992;55:78-80.

69. Berrada N, Lemeland JF, Laroche G, Thouvenot P, Piaia M. Bifidobacterium from fermented milks: Survival during gastric transit. J Dairy Sci 1991;74:409-13.

70. Marteau P, Cuillerier E, Meance S, et al. Bifidobacterium animalis strain DN-173 010 shortens the colonic transit time in healthy women: A double-blind, randomized, controlled study. Aliment Pharmacol Ther 2002;16:587-93.

71. Ivanko O. Lacidofil in the prevention of Clostridium difficile diarrhea in children. Proceedings of the Institute Rosell Conference, 2005. Italy, September 7 to 8, 2005:22-24.

72. Ma D, Forsythe P, Bienenstock J. Live Lactobacillus reuteri is essential for the inhibitory effect on tumor necrosis factor alpha-induced interleukin-8 expression. Infect Immun 2004;72(9):5308-14

73. Kim SO, Sheik HI, Ha SD, Martins A, Reid G. G-CSF-mediated inhibition of JNK is a key mechanism for Lactobacillus rhamnosusinduced suppression of TNF production in macrophages. Cell Microbiol 2006;8:1958-71.

74. Sen S, Mullan MM, Parker TJ, Woolner JT, Tarry SA, Hunter JO. Effect of Lactobacillus plantarum 299v on colonic fermentation and symptoms of irritable bowel syndrome. Dig Dis Sci 2002;47:2615-20. 


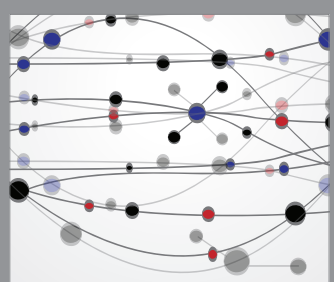

The Scientific World Journal
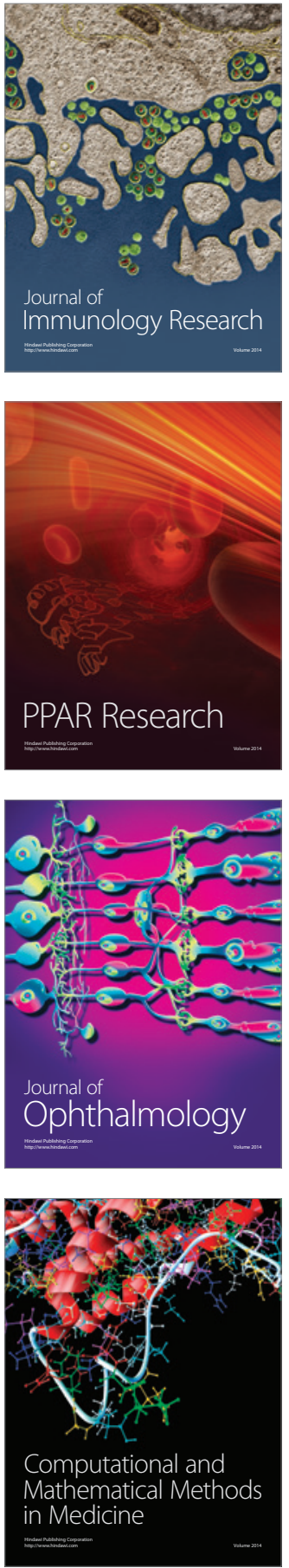

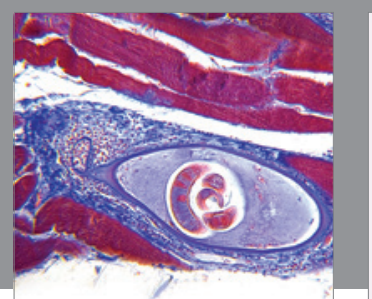

Gastroenterology Research and Practice

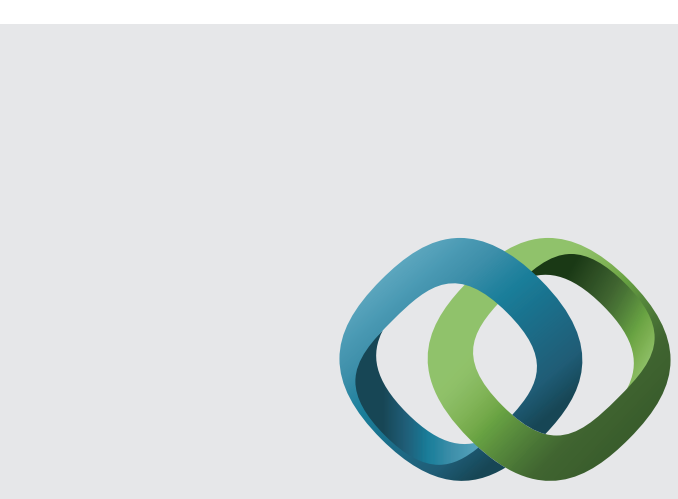

\section{Hindawi}

Submit your manuscripts at

http://www.hindawi.com
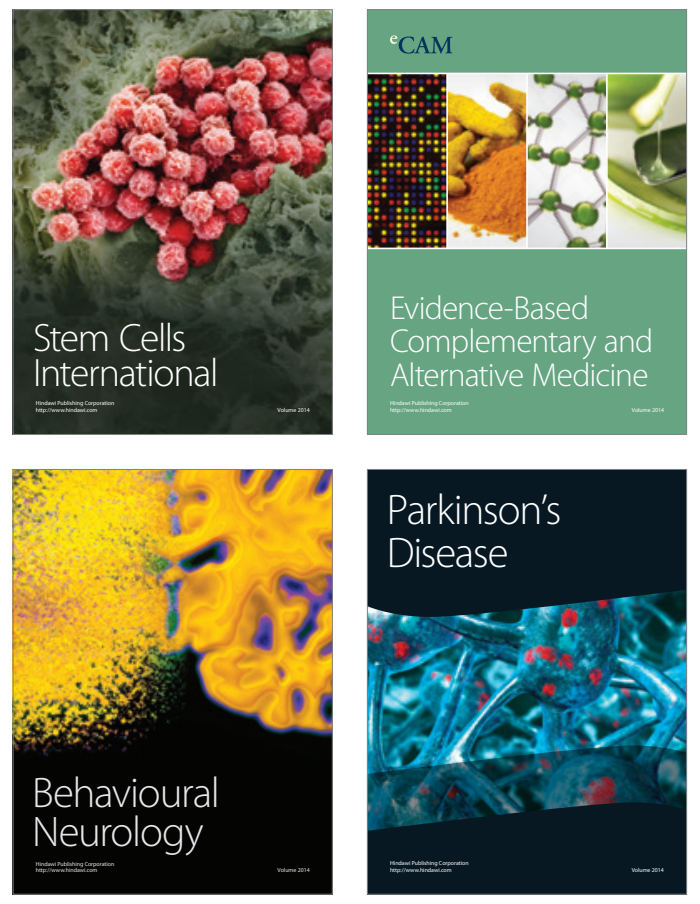
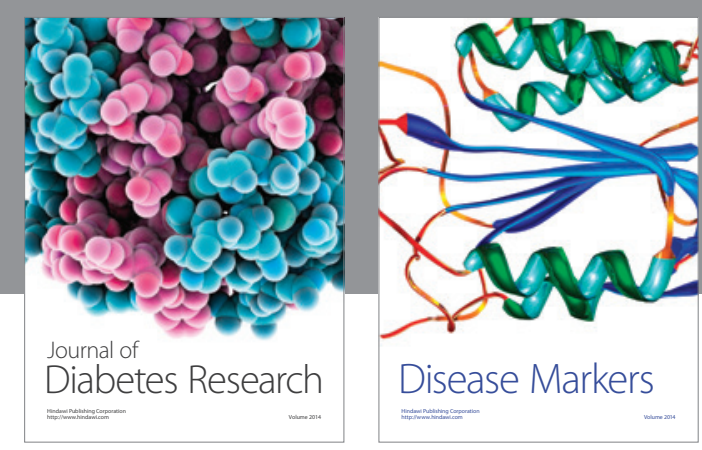

Disease Markers
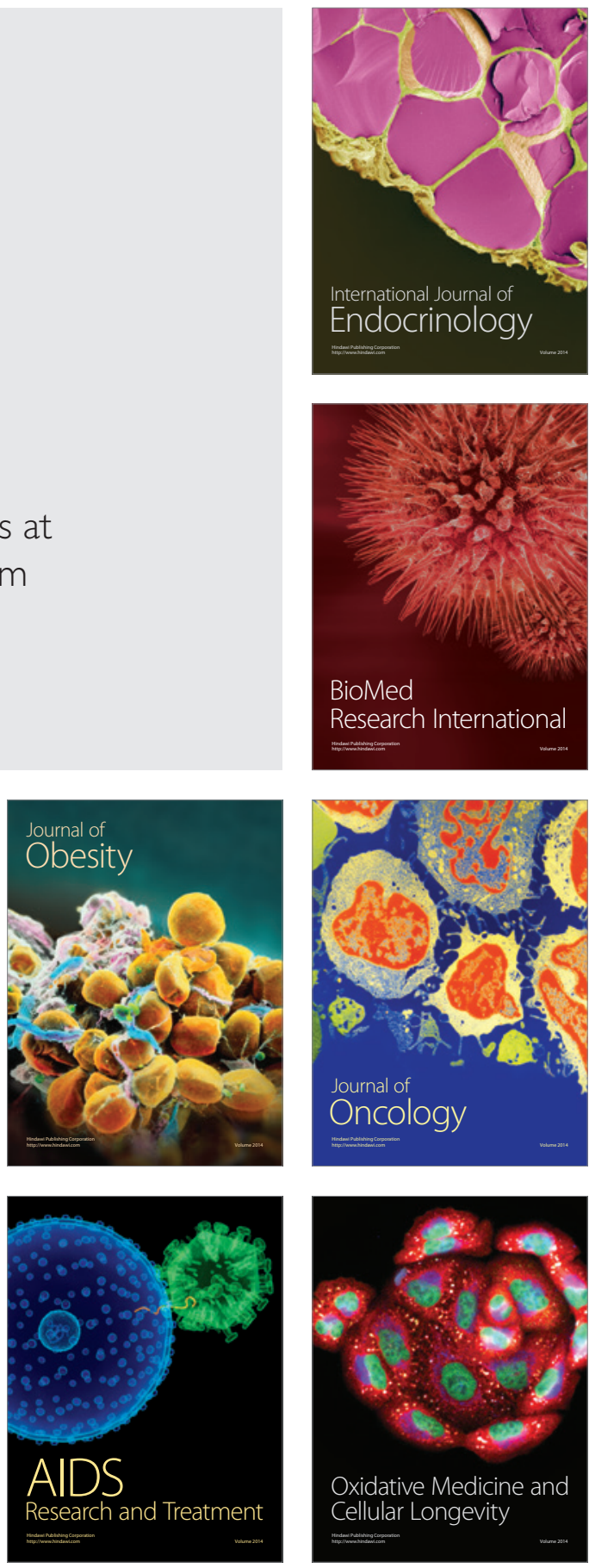